\title{
Physicochemical properties, fatty acid profile and sensory characteristics of sheep and goat meat sausages manufactured with different pork fat levels
}

\author{
Ana Leite ${ }^{\mathrm{a}}$, Sandra Rodrigues ${ }^{\mathrm{b}, \mathrm{c}}$, Etelvina Pereira ${ }^{\mathrm{c}}$, Kátia Paulos ${ }^{\mathrm{a}}$, António Filipe Oliveira ${ }^{\mathrm{a}}$, \\ José Manuel Lorenzo ${ }^{\mathrm{d}}$, Alfredo Teixeira ${ }^{\mathrm{a}, \mathrm{c}, *}$ \\ a Veterinary and Animal Research Centre (CECAV), Universidade Trás-os-Montes e Alto Douro, Portugal \\ ${ }^{\mathrm{b}}$ Mountain Research Centre, CIMO, Portugal \\ c Escola Superior Agrária/Instituto Politécnico de Bragança, Campus Sta Apolónia Apt, Bragança 1172 5301-855, Portugal \\ d Centro Tecnológico de la Carne de Galicia, Rúa Galicia N 4, Parque Tecnológico de Galicia, San Cibrán das Viñas, Ourense 32900, Spain
}

\section{A R T I C L E I N F O}

\section{Article history:}

Received 24 November 2014

Received in revised form 14 March 2015

Accepted 17 March 2015

Available online 25 March 2015

\section{Keyword:}

Cull animal

Fat content

Goats and sheep meat

Discriminant analysis

\begin{abstract}
A B S T R A C T
The effect of three pork backfat levels ( $0 \%$ vs. $10 \%$ vs. $30 \%$ ) on chemical composition, fatty acid profile and sensory properties on sheep and goat meat sausages was studied. All physicochemical parameters were affected by the addition of pork backfat in both types of sausages. Sausages manufactured with 30\% of pork backfat showed the lowest moisture and protein contents and the highest total fat content. The lower $a_{\mathrm{w}}$ values in sausages manufactured with higher fat content while in $\mathrm{pH}$ happened the reverse situation. The addition of pork backfat modified the total fatty acid profile, prompting a significant drop in the relative percentages of C14:0, C16:0, C17:0, C17:1, C18:0 and TVA (trans-vaccenic acid), together with a marked increase in oleic and linoleic acids. Finally, in goat sausages, the fat content significantly affected sensory parameters: taste, texture and overall acceptability $(P<0.05)$. As expected, all physicochemical parameters were affected by the addition of pork backfat in both types of sausages.
\end{abstract}

(C) 2015 Elsevier Ltd. All rights reserved.

\section{Introduction}

In Portugal, sheep and goats are extensively managed and raised for milk and meat (Teixeira, 1995). Lambs and kids produced in Mediterranean countries of the European Union are traditionally commercialized as quality brands with protected designation of origin (PDO) and protected geographical indications (PGI) (Teixeira, Delfa, \& Alberti, 1998). However, there are animals that come out of these quality brands, particularly the culled ones or those with weight or age that cannot be considered as a PDO or PGI labels.

These animals have very low consumer acceptability and consequently a low commercial value and a strategy to give value to those animals would be welcome by producers as well as butchers, meat industry or supermarkets. Value may be added to final products by decreasing costs or improving relative value of the final product (McMillin \& Brock, 2005). With this goal, there are several recently studies in goat and sheep meat processed products: Cosenza, Williams, Johnson, Sims, and McGowan (2003) evaluated the quality and consumer acceptability of cabrito smoked sausage, using goat meat as the sole meat ingredient;

\footnotetext{
* Corresponding author at: Campus Sta Apolónia Apt 1172, Bragança 5301-855, Portugal. Tel.: + 351273 303206; fax: + 351273325405 .

E-mail address: teixeira@ipb.pt (A. Teixeira).
}

Polpara, Sornprasitt, and Wattanachant (2008) studied the quality characteristics of raw and canned goat meat in water, brine, oil and Thai curry during storage; Das, Anjaneyulu, Thomas, and Kondaiah (2009) studied the effect of different fats on the quality of goat meat patties; Teixeira, Pereira, and Rodrigues (2011) studied the effect of salting, air-drying and ageing processes in a new goat meat product "manta" and Oliveira et al. (2014) evaluated the quality of ewe and goat meat cured product mantas.

The Portuguese traditional sausages are unique products that have usually originated in geographical areas that are, in general, associated with its trade name and have a strong connection to this region and they quality is clearly influenced by breed of animals, reared system, climate and manufacturing technology. A project between a research center (Carcass and Meat Quality and Technology Laboratory of Agrarian School of Bragança), two breeder associations (ANCRAS-Serrana Goat National Association of Breed Producers and ACOB-Bragançana Sheep National Association of Breed Producers) and a meat manufacturing industry (Bísaro Salsicharia Tradicional) was developed to add value to these animals, creating two new products, a raw fresh meat sausage from Churra Galega Transmontana ewes and Serrana goats. Thus, the aim of this study was to characterize the physicochemical composition of these sausages and to study the effect of the addition of different pork backfat levels from a local breed Bísara on chemical composition, 
fatty acid profile and sensory properties of sheep and goat sausages. These sausages from meat of culled sheep and goats allow to valorize animals whose marketing value is very low by producing a product that in a future could be commercialized and consumed in halal and kosher markets.

\section{Materials and methods}

\subsection{Sausages manufacturing and sampling}

Two types of fresh sausages were manufactured, mincing and mixing sheep and goat meats with two levels of Bísaro pork backfat fat $(10 \%$ and $30 \%)$ salt $(2.4 \%)$, peppers $(0.3 \%)$, sugar $(0.1 \%)$, water and rendimix®. A control batch without pork fat was also manufactured. Meats used for manufacturing include sheep and goat trimmings from local breeds: Churra Galega Bragançana ewes and Serrana goats aged between 5 and 7 years old, with an average $20 \mathrm{~kg}$ carcass weight. Pork meat was also from females weighing between 100 and $120 \mathrm{~kg}$ body weight of a local breed, Bísaro. Animals were slaughtered in the official slaughterhouse of Bragança (Trás-os-Montes region-northeast Portugal). Pigs were slaughtered on arrival to reduce the stress once time and distances travelled were relatively short ( $5 \mathrm{~km})$. Animals were washed and electrically stunned in an appropriate stunning box prior to bleeding. No electrical stimulation of carcasses method was used. Carcasses of pigs were scalding in water at $60{ }^{\circ} \mathrm{C}$. After weighing, carcasses were cooled at $4{ }^{\circ} \mathrm{C}$ for 12 and $24 \mathrm{~h}$ for pigs and sheep or goats, respectively. Carcasses were previously deboned and cleaned from nerves, tendons and connective tissues before raw meat was processed at the manufacturing meat industry. The mixing was then stuffed into $34-36 \mathrm{~mm}$ pork casings, hung and stabilized in a climate chamber at $13{ }^{\circ} \mathrm{C}$ and $80 \%$ with a relative humidity, packaged in polyamidepolyethylene bags and stored in a refrigerator at $4{ }^{\circ} \mathrm{C}$ until laboratory analysis.

For each type of sausages ( sheep and goat) and the three treatments ( $0 \%, 10 \%$ and $30 \%$ pork fat), 22 samples were randomly selected from each lot of sausages, for a total of 132 sausages. Samples were divided into the following groups: S0, S10 and S30 for sheep sausages without pork fat and with $10 \%$ and $30 \%$ of pork fat, respectively; and G0, G10 and G30 for goat sausages without pork fat and with $10 \%$ and $30 \%$ of pork fat, respectively. Each group studied corresponds to an individual lot, produced in an independent day (six lots in total, six manufacturing days). Three replicates of each sample were analyzed.

\subsection{Physicochemical analysis and chemical composition}

The measurement of $\mathrm{pH}$ was performed according to the Portuguese standard NP 3441 (2008), using a portable potentiometer equipped with a specific electrode penetrator, and calibrated with standard buffers with the following $\mathrm{pH} 4,01-7,02$. Water activity was determinated using a water activity probe (HygroPalmAw1 rotronic 8303, Bassersdorf, Switzerland) according to (AOAC, 1990). The determination of moisture was performed according to the Portuguese standard NP 1614 (2009). Three to $5 \mathrm{~g}$ of sample was added to $5 \mathrm{~mL}$ of ethanol. After that, samples were dried in a drying oven (Raypa DO150 , Barcelona, Spain) during $24 \mathrm{~h}$ at $103^{\circ} \mathrm{C} \pm 2{ }^{\circ} \mathrm{C}$. Protein determination was carried out following the Portuguese standard NP 1612 (2002) using (Kjeldahl Sampler System K370 and Digest System K-437, Flawil, Switzerland). One and a half to $3 \mathrm{~g}$ of sample was put in mineralization tubes with two catalyst tablets and $25 \mathrm{~mL}$ of sulfuric acid (97\%). After mineralization completion, the distillation procedure was carried out. Finally, the distillate was titrated with hydrochloric acid solution and the required volume record. For total fat content determination, samples were subjected to a liquid-solid extraction using petroleum ether in an extractor apparatus (AnkomHCI Hydrolysis System, Macedon NY, USA) at $90{ }^{\circ} \mathrm{C}$ for $60 \mathrm{~min}$. The total fat content was obtained based on gravimetric difference. Ashes were assessed according to the
Portuguese standard NP 1615 (2002). To 3-5 g of sample, we added $1 \mathrm{~mL}$ of magnesium acetate in crucibles. After that, the samples were subject to $550{ }^{\circ} \mathrm{C} \pm 25{ }^{\circ} \mathrm{C}$ during 5-6 h in muffle furnace (Vulcan BOX Furnace Model 3-550, Yucaipa, USA).

\subsection{Fatty acid composition}

Total lipids were extracted from $25 \mathrm{~g}$ of ground meat sample, according to the Folch, Lees, and Stanley (1957) procedure. Fifty milligrams of fat was used to determine fatty acid profile. Fatty acids were transesterified following the method described by Shehata, de Man, and Alexander (1970) with some modifications; $4 \mathrm{~mL}$ of a sodium methoxide (2) solution were added to the fraction, vortexed every 5 min during $20 \mathrm{~min}$ at room temperature, then $4 \mathrm{~mL}$ of a $\mathrm{H}_{2} \mathrm{SO}_{4}$ solution (in methanol at 50\%), vortexed a few seconds and vortexed again before adding $2 \mathrm{~mL}$ of distilled water. Organic phase (containing fatty acids methyl esters) was extracted with $2.5 \mathrm{~mL}$ of hexane. Separation and quantification of the FAMEs was carried out using a gas chromatograph (GC-Agilent 6890 N; Agilent Technologies Spain, S.L., Madrid, Spain) equipped with a flame ionization detector and an automatic sample injector HP 7683, and using a Supelco SPTM-2560 fused silica capillary column ( $100 \mathrm{~m}, 0.25 \mathrm{~mm}$ i.d., $0.2 \mu \mathrm{m}$ film thickness). The chromatographic conditions were as follows: initial column temperature $120{ }^{\circ} \mathrm{C}$, maintaining this temperature for $5 \mathrm{~min}$, programmed to increase at a rate of $5^{\circ} \mathrm{C} \cdot \min -1$ up to $200^{\circ} \mathrm{C}$, maintaining this temperature for $2 \mathrm{~min}$, then at $1{ }^{\circ} \mathrm{C} \cdot \min -1$ up to $230^{\circ} \mathrm{C}$, maintaining this temperature for $3 \mathrm{~min}$. The injector and detector were maintained at 260 and $280{ }^{\circ} \mathrm{C}$, respectively. Helium was used as the carrier gas at a constant flow-rate of $1.1 \mathrm{~mL} \cdot \min -1$, with the column head pressure set at 35.56 psi. The split ratio was $1: 50$ and $1 \mu \mathrm{L}$ of solution was injected. Nonadecanoic acid (C19:0) at $0.3 \mathrm{mg} \cdot \mathrm{mL}-1$ was used as internal standard and added to the samples prior methylation. Individual FAMEs were identified by comparing their retention times with those of authenticated standards (Supelco 37 component FAME Mix). Data regarding FAME composition were expressed in percentage according to the weight of the total identified FAMEs.

\subsection{Consumers sensory evaluation}

Sensory evaluation of goats and sheep's fresh sausages was performed by a consumers' panel, in accordance with the Portuguese Norm (NP8586-1, 2001). The consumers' panel was constituted by 26 elements from the staff of the Polytechnic Institute of Bragança (aged between 19 and 64 years old) without previous training during two sessions evaluating the following sensory attributes: taste, texture, spiciness and overall acceptability. An unstructured $10 \mathrm{~cm}$ scale with anchors at the extremities (from $0 \mathrm{~cm}$-"do not like" to $10 \mathrm{~cm}$-"like very much") was used. Sausages samples were cooked in the grill until the internal temperature reached about $75^{\circ} \mathrm{C}$. Afterwards, sausages were divided into pieces $0.5 \mathrm{~cm}$ thick, labeled with random codes and stored at $60-70{ }^{\circ} \mathrm{C}$. During the testing, we provided unsalted crackers and water in order to clean the mouth for each sample.

\subsection{Statistical analysis}

Data were analysed using the mixed model (Henderson, 1973):

$\mathrm{y}=\mathrm{X} \beta+\mathrm{Z} \gamma+\varepsilon$

$\boldsymbol{\gamma}$ is an unknown vector of random-effects parameters with known design matrix $\mathbf{Z}$, and $\boldsymbol{\varepsilon}$ is an unknown random error vector whose elements are no longer required to be independent and homogeneous.

Statistical analysis was performed using the statistical package JMP Pro 11.1.1 by Copyright @ $\odot 2013$ SAS Institute, Inc. Main effects (specie, fat level) and interaction were tested in mixed models as fixed effects (PROC MIXED, SAS) of treatment and the random effects of repeated 
measurements of individual sausage and three replications. General mixed models (PROC GLIMMIX, SAS) with identical fixed and random effects were used to find the probability of the differences as a result of treatments (specie and fat level). The predicted means obtained were ranked based on pair-wise least significance differences and compared using the t student test and the significant levels of 0.05, 0.01 and 0.001 .

For sensorial analysis, a similar model was used with specie, fat level and their interaction as fixed effects. The random effect was excluded and a repeated covariance structure was fitted with session as repetition and sample as subject using the Restricted Maximum Likelihood (REML) Method.

To know which group of variables within the fatty acid profile would be more useful to classify and distinguish the six groups of sausages; a discriminant analysis was performed using the linear, common covariance and the stepwise variable selection methods (PROC DISCRIM, SAS). The efficiency of the discriminant power of the models selected was assessed by the test of the Wilks' lambda value. Results were analysed in terms of the absolute assignment of individuals to the preassigned group and the variance explained by each canonical resemblance as well as by the analysis of the scoring coefficients.

\section{Results and discussions}

\subsection{Physicochemical analysis and chemical composition}

Table 1 shows the effect of added pork backfat on the $\mathrm{pH}, a_{\mathrm{w}}$ and chemical composition of sheep and goat sausages. Regarding $a_{\mathrm{w}}$, significant $(P<0.001)$ differences were observed among batches. The G30\% showed the lowest values $(0.92 \pm 0.002)$ compared to control sausages $(0.97 \pm 0.002)$, while $\mathrm{G} 10 \%$ presented intermediate values $(0.95 \pm$ 0.002 ) in agreement with Gómez and Lorenzo (2013) who observed lower $a_{\mathrm{w}}$ values in sausages manufactured with higher fat content. However, sheep sausages displayed a different behavior, since the S10\% showed the lowest values (0.92). In addition, Lorenzo and Franco (2012) and Olivares, Navarro, Salvador, and Flores (2010) did not observe significant $(P>0.05)$ differences in $a_{\mathrm{w}}$ values among sausages manufactured with fat content.

On the other hand, the $\mathrm{pH}$ values were affected $(P<0.001)$ by fat content. In our study, both sausages presented higher $\mathrm{pH}$ values in samples manufactured with $30 \%$ of pork backfat compared to control ones. This result is in agreement with those reported by Lorenzo and Franco (2012) and Olivares et al. (2010) who observed lower pH values in low fat sausages compared to high fat sausages. However, other authors (Liaros, Katsanidis, \& Bloukas, 2009; Salazar, García, \& Selgas, 2009) did not observe an effect of fat content on $\mathrm{pH}$ values. According to $\mathrm{pH}$ and $a_{\mathrm{w}}$ values, meat products can be classified as "easily perishable," "perishable" and "stable" (Ambrosiadis, Soultos, Abrahim, \& Bloukas, 2004). The sausages manufactured with sheep and goat meat can be classified in the group of fresh product, high water activity $(>0.90)$, whose conservation is very important to reduce or prevent any kind of alteration/degradation and should be consumed over a period of time indicated for consuming fresh product, usually $72 \mathrm{~h}$.

As expected, both control sausages had higher moisture content than the manufactured with 10 and $30 \%$ of pork backfat (Table 1). Similar results were previously reported by other authors (Gómez \& Lorenzo, 2013; Lorenzo \& Franco, 2012; Lorenzo, Purriños, Bermúdez, Temperan, \& Franco, 2011; Olivares et al., 2010) who found higher water levels in low fat sausages. The fat content showed significant differences $(P<0.001)$ among batches. This is an expected result because the batches were manufactured with different fat content. The fat content of the goat and sheep sausages was lower than formulated as the batches contained $11.9 \%$ and $21.8 \%$ and $20.1 \%$ and $23.5 \%$ fat for goat and sheep sausages, respectively, instead of the 10 and 30\% formulated. Protein content also showed significant differences $(P<0.001)$ among batches, presenting mean values of $18.9 \%, 16.8 \%$ and $14.3 \%$ for goat sausages manufactured with $0 \%, 10 \%$ and $30 \%$ of pork backfat, respectively, and mean values of $18.2 \%, 15.5 \%$ and $14.1 \%$ for sheep sausages manufactured with $0 \%, 10 \%$ and $30 \%$ of pork backfat, respectively. This outcome is in agreement with those reported by Gómez and Lorenzo (2013) who noticed lower protein content in sausages manufactured with high fat content. Statistical analysis also showed that ash content decreased significantly $(P<0.001)$ with the increase of fat content in both type of sausages (Table 1 ) as was observed by Turner, Cassida, and Zerby (2014), who found values between $4.2 \%$ and $4.3 \%$ in goat meat.

\subsection{Fatty acid composition}

Table 2 shows the effect of added pork backfat on the fatty acid profile of sheep and goat sausages. The relative percentages of most fatty acids differed significantly as a function of the percentage added pork backfat. Significant $(P<0.001)$ differences were found between goat and sheep sausages regarding saturated fatty acid (SFA), monounsaturated fatty acid (MUFA) and polyunsaturated fatty acid (PUFA). The total amount of SFA in the goat and sheep sausages made with added pork backfat decreased by approximately 6-9\% and $2.5-6.5 \%$, respectively compared to the controls.

G0 (control) had the highest levels of C14:0, C14:1, C16:0, C16:1, $\mathrm{C} 17: 0, \mathrm{C} 17: 1, \mathrm{C} 18: 0$ and TVA, and the lowest level of C18:1n9, C18:1n7, C18:2n6, C18:3n3, C20:0 and C20:1n9. On the other hand, S0 had the highest amounts of C14:0, C14:1, C16:1, C17:0, C17:1, C18:0

Table 1

Predicted values (mean \pm standard error) for physicochemical composition.

\begin{tabular}{|c|c|c|c|c|c|c|c|c|c|}
\hline & \multicolumn{3}{|c|}{ Goat meat sausages } & \multicolumn{3}{|c|}{ Sheep meat sausages } & \multicolumn{3}{|l|}{$P$-values } \\
\hline & G0\% & G10\% & G30\% & S0\% & S10\% & S30\% & Species & Fat Level & Sp $\times$ FL \\
\hline$a_{\mathrm{w}}$ & $0.97 \pm 0.002^{\mathrm{A}}$ & $0.95 \pm 0.002^{\mathrm{B}}$ & $0.92 \pm 0.002^{\mathrm{D}}$ & $0.94 \pm 0.002^{C}$ & $0.92 \pm 0.002^{\mathrm{E}}$ & $0.94 \pm 0.002^{C}$ & $* * *$ & $* * *$ & $* * *$ \\
\hline $\mathrm{pH}$ & $5.94 \pm 0.011^{\mathrm{DC}}$ & $6.10 \pm 0.011^{\mathrm{E}}$ & $6.16 \pm 0.011^{\mathrm{A}}$ & $5.93 \pm 0.011^{\mathrm{DC}}$ & $5.93 \pm 0.011^{C}$ & $6.13 \pm 0.011^{\mathrm{BE}}$ & $* * *$ & $* * *$ & $* * *$ \\
\hline Ash (\%) & $4.30 \pm 0.03^{\mathrm{A}}$ & $4.08 \pm 0.03^{\mathrm{B}}$ & $3.75 \pm 0.03^{C}$ & $4.29 \pm 0.03^{\mathrm{A}}$ & $4.05 \pm 0.03^{\mathrm{B}}$ & $3.70 \pm 0.03^{\mathrm{C}}$ & $\mathrm{ns}^{*}$ & $* * *$ & $\mathrm{~ns}^{* *}$ \\
\hline Moisture (\%) & $69.53 \pm 0.18^{\mathrm{A}}$ & $66.74 \pm 0.18^{\mathrm{B}}$ & $59.46 \pm 0.18^{C}$ & $67.27 \pm 0.18^{\mathrm{D}}$ & $60.52 \pm 0.18^{\mathrm{E}}$ & $57.86 \pm 0.18^{\mathrm{F}}$ & $* * *$ & $* * *$ & $* * *$ \\
\hline Protein (\%) & $18.92 \pm 0.08^{\mathrm{A}}$ & $16.78 \pm 0.08^{C}$ & $14.29 \pm 0.08^{\mathrm{E}}$ & $18.16 \pm 0.08^{\mathrm{B}}$ & $15.48 \pm 0.08^{\mathrm{D}}$ & $14.13 \pm 0.08^{\mathrm{E}}$ & $* * *$ & $* * *$ & $* * *$ \\
\hline Total fat (\%) & $5.33 \pm 0.40^{\mathrm{A}}$ & $11.89 \pm 0.40^{\mathrm{B}}$ & $21.81 \pm 0.40^{C}$ & $8.70 \pm 0.40^{\mathrm{D}}$ & $20.11 \pm 0.40^{\mathrm{E}}$ & $23.50 \pm 0.39^{\mathrm{F}}$ & $* * *$ & $* * *$ & $* * *$ \\
\hline
\end{tabular}

ns-not significant.

S0 sheep sausages without pork fat.

S10 sheep sausages with $10 \%$ of pork fat.

S30 sheep sausages with $30 \%$ of pork fat.

G0 goat sausages without pork fat.

G10 goat sausages with $10 \%$ of pork fat.

G30 goat sausages with $30 \%$ of pork fat.

* $P<0.05$.

** $P<0.01$.

*** $P<0.001$ 
Table 2

Predicted values (mean \pm standard error) for fatty acids profile.

\begin{tabular}{|c|c|c|c|c|c|c|c|c|c|}
\hline \multirow[b]{2}{*}{ Fatty acid } & \multicolumn{3}{|c|}{ Goat meat sausages } & \multicolumn{3}{|c|}{ Sheep meat sausages } & \multicolumn{3}{|l|}{$P$-values } \\
\hline & $\mathrm{G} 0 \%$ & G10\% & G30\% & $\mathrm{S} 0 \%$ & $\mathrm{~S} 10 \%$ & S30\% & Species & Fat Level & Sp x FL \\
\hline $\mathrm{C} 12: 0$ & $0.14 \pm 0.02^{\mathrm{A}}$ & $0.13 \pm 0.02^{\mathrm{A}}$ & $0.13 \pm 0.02^{\mathrm{A}}$ & $0.10 \pm 0.02^{\mathrm{A}}$ & $0.11 \pm 0.02^{\mathrm{A}}$ & $0.12 \pm 0.02^{\mathrm{A}}$ & ns & ns & ns \\
\hline C14:0 & $2.56 \pm 0.03^{\mathrm{A}}$ & $1.94 \pm 0.03^{\mathrm{D}}$ & $1.68 \pm 0.03^{F}$ & $2.38 \pm 0.03^{\mathrm{B}}$ & $2.07 \pm 0.03^{C}$ & $1.85 \pm 0.03^{\mathrm{E}}$ & ns & $*$ & $* * *$ \\
\hline C14:1 & $0.42 \pm 0.03^{\mathrm{A}}$ & $0.12 \pm 0.03^{\mathrm{B}}$ & $0.07 \pm 0 . .^{03 \mathrm{DB}}$ & $0.17 \pm 0.03^{\mathrm{C}}$ & $0.09 \pm 0.03^{\mathrm{DB}}$ & $0.06 \pm 0.03^{\mathrm{DB}}$ & $* * *$ & $* * *$ & $* * *$ \\
\hline $\mathrm{C} 16: 0$ & $24.21 \pm 0.15^{\mathrm{A}}$ & $23.15 \pm 0.15^{\mathrm{B}}$ & $22.42 \pm 0.15^{\mathrm{C}}$ & $22.70 \pm 0.15^{\mathrm{BC}}$ & $22.95 \pm 0.15^{\mathrm{B}}$ & $22.75 \pm 0.15^{\mathrm{BC}}$ & $* * *$ & $* * *$ & $* * *$ \\
\hline C16:1 & $2.57 \pm 0.11^{\mathrm{A}}$ & $2.20 \pm 0.11^{\mathrm{B}}$ & $2.07 \pm 0.11^{\mathrm{B}}$ & $2.31 \pm 0.11^{\mathrm{B}}$ & $2.14 \pm 0.11^{\mathrm{B}}$ & $2.03 \pm 0.11^{\mathrm{B}}$ & $*$ & $* * *$ & $* *$ \\
\hline $\mathrm{C} 17: 0$ & $1.21 \pm 0.01^{\mathrm{B}}$ & $0.67 \pm 0.01^{\mathrm{D}}$ & $0.48 \pm 0.01^{\mathrm{F}}$ & $1.34 \pm 0.01^{\mathrm{A}}$ & $1.00 \pm 0.01^{\mathrm{C}}$ & $0.61 \pm 0.01^{\mathrm{E}}$ & $* * *$ & $* * *$ & $* * *$ \\
\hline $\mathrm{C} 17: 1$ & $0.99 \pm 0.02^{\mathrm{A}}$ & $0.46 \pm 0.02^{\mathrm{C}}$ & $0.34 \pm 0.02^{\mathrm{D}}$ & $0.73 \pm 0.02^{\mathrm{B}}$ & $0.51 \pm 0.02^{\mathrm{C}}$ & $0.36 \pm 0.02^{\mathrm{D}}$ & $* * *$ & $* * *$ & $* * *$ \\
\hline C18:0 & $18.97 \pm 0.21^{\mathrm{A}}$ & $15.43 \pm 0.21^{C}$ & $12.96 \pm 0.21^{\mathrm{D}}$ & $18.50 \pm 0.21^{\mathrm{A}}$ & $16.51 \pm 0.21^{\mathrm{B}}$ & $13.51 \pm 0.21^{\mathrm{D}}$ & $\mathrm{ns}^{* *}$ & $* * *$ & $* * *$ \\
\hline C18:1n9t & $0.61 \pm 0.14^{\mathrm{A}}$ & $0.73 \pm 0.14^{\mathrm{A}}$ & $0.37 \pm 0.14^{\mathrm{A}}$ & $0.55 \pm 0.14^{\mathrm{A}}$ & $0.55 \pm 0.14^{\mathrm{A}}$ & $0.40 \pm 0.14^{\mathrm{A}}$ & ns & $*$ & ns \\
\hline C18:1n9c & $38.91 \pm 0.29^{A}$ & $41.36 \pm 0.29^{\mathrm{BC}}$ & $42.48 \pm 0.29^{\mathrm{D}}$ & $40.93 \pm 0.29^{B}$ & $41.28 \pm 0.29^{B}$ & $42.00 \pm 0.29^{C}$ & $* * *$ & $* * *$ & $* * *$ \\
\hline C18:1n11t & $1.40 \pm 0.18^{\mathrm{B}}$ & $0.49 \pm 0.18^{C}$ & $0.58 \pm 0.18^{\mathrm{DC}}$ & $2.26 \pm 0.18^{A}$ & $1.64 \pm 0.18^{\mathrm{B}}$ & $0.84 \pm 0.18^{C}$ & $* * *$ & $* * *$ & $* * *$ \\
\hline C18:1n7c & $0.95 \pm 0.16^{\mathrm{CD}}$ & $1.52 \pm 0.16^{\mathrm{B}}$ & $2.38 \pm 0.16^{A}$ & $1.14 \pm 0.16^{\mathrm{BC}}$ & $1.66 \pm 0.16^{\mathrm{B}}$ & $2.25 \pm 0.16^{\mathrm{A}}$ & ns & ns & $* * *$ \\
\hline C18:2n6c & $3.74 \pm 0.46^{\mathrm{D}}$ & $8.22 \pm 0.47^{\mathrm{B}}$ & $10.60 \pm 0.46^{A}$ & $3.91 \pm 0.46^{\mathrm{D}}$ & $6.62 \pm 0.46^{\mathrm{C}}$ & $9.95 \pm 0.47^{\mathrm{A}}$ & ns & $* * *$ & $* * *$ \\
\hline $\mathrm{C} 18: 3 \mathrm{n} 3 \mathrm{c}$ & $0.52 \pm 0.02^{\mathrm{E}}$ & $0.61 \pm 0.02^{\mathrm{D}}$ & $0.68 \pm 0.02^{\mathrm{C}}$ & $0.76 \pm 0.02^{\mathrm{A}}$ & $0.75 \pm 0.02^{\mathrm{A}}$ & $0.75 \pm 0.02^{\mathrm{A}}$ & $* * *$ & $* * *$ & $* * *$ \\
\hline C20:0 & $0.09 \pm 0.01^{\mathrm{E}}$ & $0.22 \pm 0.01^{\mathrm{B}}$ & $0.25 \pm 0.01^{\mathrm{AB}}$ & $0.14 \pm 0.01^{\mathrm{D}}$ & $0.18 \pm 0.01^{\mathrm{C}}$ & $0.23 \pm 0.01^{\mathrm{AB}}$ & ns & $* * *$ & $* * *$ \\
\hline C20:1n9 & $0.12 \pm 0.02^{\mathrm{E}}$ & $0.74 \pm 0.02^{C}$ & $0.99 \pm 0.02^{\mathrm{A}}$ & $0.14 \pm 0.02^{\mathrm{E}}$ & $0.55 \pm 0.02^{\mathrm{D}}$ & $0.90 \pm 0.02^{\mathrm{B}}$ & $* * *$ & $* * *$ & $* * *$ \\
\hline SFA & $47.79 \pm 0.32^{\mathrm{F}}$ & $41.86 \pm 0.33^{C}$ & $38.12 \pm 0.32^{\mathrm{A}}$ & $45.82 \pm 0.32^{\mathrm{E}}$ & $43.30 \pm 0.32^{\mathrm{D}}$ & $39.36 \pm 0.33^{\mathrm{B}}$ & $* * *$ & $* * *$ & $* * *$ \\
\hline MUFA & $46.01 \pm 0.34^{C}$ & $47.69 \pm 0.34^{\mathrm{B}}$ & $49.29 \pm 0.34^{\mathrm{A}}$ & $48.23 \pm 0.34^{\mathrm{B}}$ & $48.48 \pm 0.34^{\mathrm{AB}}$ & $48.84 \pm 0.34^{\mathrm{AB}}$ & $* * *$ & $* * *$ & $* * *$ \\
\hline PUFA & $6.20 \pm 0.47^{\mathrm{B}}$ & $10.45 \pm 0.47^{C}$ & $12.59 \pm 0.47^{\mathrm{A}}$ & $5.94 \pm 0.47^{\mathrm{B}}$ & $8.22 \pm 0.47^{\mathrm{D}}$ & $11.80 \pm 0.47^{\mathrm{A}}$ & $* *$ & $* * *$ & $* * *$ \\
\hline MUFA + PUFA & $52.21 \pm 0.32^{\mathrm{F}}$ & $58.14 \pm 0.33^{C}$ & $61.88 \pm 0.32^{\mathrm{A}}$ & $54.18 \pm 0.32^{\mathrm{E}}$ & $56.70 \pm 0.32^{\mathrm{D}}$ & $60.65 \pm 0.33^{\mathrm{B}}$ & ns & $*$ & $* * *$ \\
\hline PUFA/SFA & $0.13 \pm 0.01^{\mathrm{D}}$ & $0.25 \pm 0.01^{\mathrm{B}}$ & $0.33 \pm 0.01^{\mathrm{A}}$ & $0.13 \pm 0.01^{\mathrm{D}}$ & $0.19 \pm 0.01^{\mathrm{C}}$ & $0.30 \pm 0.01^{\mathrm{A}}$ & ns & $*$ & $* * *$ \\
\hline PUFA-n3 & $1.08 \pm 0.08^{\mathrm{B}}$ & $1.35 \pm 0.08^{A}$ & $0.97 \pm 0.08^{\mathrm{BC}}$ & $1.11 \pm 0.08^{\mathrm{B}}$ & $1.07 \pm 0.08^{\mathrm{C}}$ & $0.98 \pm 0.08^{\mathrm{B}}$ & $* * *$ & $* * *$ & $* * *$ \\
\hline PUFA-n6 & $5.12 \pm 0.12^{\mathrm{E}}$ & $9.47 \pm 0.12^{C}$ & $11.62 \pm 0.12^{\mathrm{A}}$ & $4.83 \pm 0.12^{\mathrm{E}}$ & $7.47 \pm 0.12^{\mathrm{D}}$ & $10.82 \pm 0.12^{\mathrm{B}}$ & $* * *$ & $* * *$ & $* * *$ \\
\hline PUFA-n6/n3 & $4.78 \pm 0.42^{C}$ & $7.43 \pm 0.42^{\mathrm{B}}$ & $11.97 \pm 0.42^{\mathrm{A}}$ & $4.38 \pm 0.42^{C}$ & $7.08 \pm 0.42^{\mathrm{B}}$ & $11.08 \pm 0.42^{\mathrm{A}}$ & ns & $* * *$ & $* * *$ \\
\hline
\end{tabular}

ns-not significant.

SFA, saturated fatty acids.

MUFA, monounsaturated fatty acids.

PUFA, polyunsaturated fatty acids.

SO sheep sausages without pork fat.

S10 sheep sausages with $10 \%$ of pork fat.

S30 sheep sausages with $30 \%$ of pork fat.

G0 goat sausages without pork fat.

G10 goat sausages with $10 \%$ of pork fat.

G30 goat sausages with $30 \%$ of pork fat.

$* \quad P<0.05$.

** $P<0.01$.

*** $P<0.001$.

and TVA, and the lowest level of C18:1n9, C18:1n7, C18:2n6, C20:0 and $\mathrm{C} 20: 1 \mathrm{n} 9$. The addition of pork backfat modified the total fatty acid profile, prompting a significant drop in the relative percentages of C14:0, C16:0, C17:0, C17:1, C18:0 and TVA, together with a marked increase in C18:1n9 and C18:2n6 fatty acids, the predominant fatty acids in pork backfat (Lorenzo, Montes, Purriños, Cobas, \& Franco, 2012).

In both types of sausages, the most abundant fatty acids were, in decreasing order: C18:1n9, C16:0, C18:0 and C18:2n6 fatty acids. The relatively high proportion of the latter in sausages manufactured with added pork backfat ( $8.85 \%$, on average), which was less than stearic acid, demonstrated the presence of pork backfat as a source of fat in both types of sausages. A similar result was observed by Bovolenta et al. (2008) in sheep sausages manufactured with different pork lard contents. In fact, linoleic acid levels in lean goat and sheep meat (4.27\% and 3.24\%, respectively, Banskalieva, Sahlu, \& Goetsch, 2000) are one third of those in pork fat, particularly in dorsal fat $(12 \%$, Lorenzo et al., 2012).

The PUFA/SFA ratio is one of the main parameters used to assess the nutritional quality of the lipid fractions of foods. The British Department of Health (1994) recommends a PUFA/SFA ratio between 0.4 and 0.5. In this study, the goat and sheep sausages showed ratios between 0.13 and 0.33. In this sense, the addition of pork backfat improved this ratio, prompting a significant $(P<0.05)$ increased, showing the highest ratios the sausages manufactured with $30 \%$ of pork backfat. The percentage of desirable fatty acids (DFA) was defined by Rhee (1992) as follows: PUFA + MUFA + C18:0. The DFA values of goat and sheep sausages manufactured with $30 \%$ of pork backfat were higher than control sausages (data not shown).
According to Banskalieva et al. (2000), the (C18:0 + C18:1)/C16:0 ratio reflects the potential effects of the different types of lipids on human health. In this study, G30 presented the highest values (2.47) compared to control sausages (2.39). However, sheep sausages showed a different behavior, showing the control groups the highest ratios. Finally, the n-6/n-3 ratio increased with the addition of pork backfat, showing the highest values in both sausages manufactured with $30 \%$ of pork backfat.

\subsection{Consumers evaluation}

The influence of added pork backfat on the sensory characteristics of sheep and goat sausages is presented in Table 3. In both types of sausages, the fat content significantly affected sensory parameters: taste $(P<0.01)$, overall acceptability $(P<0.001)$ and texture $(P<0.001)$. However, in spicy taste no display marked differences was displayed $(P>0.05)$. Concerning taste attribute, G30 showed the highest scores (7.23) compared to control (5.09) and G10 (5.75). This finding is in disagreement with those reported by Lorenzo and Franco (2012) who found higher scores for intensity taste attribute in sausages manufactured with $10 \%$ of pork fat compared to those manufactured with $30 \%$ of pork fat.

On the other hand, in both types of sausages, control samples presented higher scores for spicy taste attribute (4.83 and 5.36 for goat and sheep sausages, respectively) compared to sausages manufactured with pork fat (Table 3$)$. Fat content significantly $(P<0.001)$ affected the texture parameter in goat and sheep sausages, since control sausages presented the lowest scores. The observed differences in the perception 
Table 3

Predicted values (means \pm standard error) for de consumer's evaluation.

\begin{tabular}{|c|c|c|c|c|c|c|c|c|c|}
\hline & \multicolumn{3}{|c|}{ Goat meat sausages } & \multicolumn{3}{|c|}{ Sheep meat sausages } & \multicolumn{3}{|l|}{$P$-values } \\
\hline & G0\% & G10\% & G30\% & S0\% & $\mathrm{S} 10 \%$ & S30\% & Species & Fat Level & Sp $\times F L$ \\
\hline Taste & $5.09 \pm 0.05^{\mathrm{E}}$ & $5.75 \pm 0.05^{\mathrm{B}}$ & $7.23 \pm 0.05^{\mathrm{A}}$ & $5.88 \pm 0.05^{\mathrm{D}}$ & $6.37 \pm 0.05^{\mathrm{B}}$ & $6.10 \pm 0.05^{\mathrm{C}}$ & ns & $* *$ & $* * *$ \\
\hline Spicy taste & $4.83 \pm 0.55^{\mathrm{A}}$ & $4.61 \pm 0.55^{\mathrm{A}}$ & $4.78 \pm 0.55^{\mathrm{A}}$ & $5.36 \pm 0.56^{\mathrm{A}}$ & $4.13 \pm 0.56^{\mathrm{A}}$ & $4.02 \pm 0.56^{\mathrm{A}}$ & $\mathrm{ns}^{*}$ & ns & ns \\
\hline Texture & $5.18 \pm 0.06^{\mathrm{D}}$ & $6.17 \pm 0.06^{C}$ & $7.56 \pm 0.06^{\mathrm{A}}$ & $5.40 \pm 0.04^{\mathrm{D}}$ & $6.83 \pm 0.04^{\mathrm{B}}$ & $6.27 \pm 0.04^{\mathrm{DB}}$ & ns & *** & $* * *$ \\
\hline Overall acceptability & $5.12 \pm 0.06^{\mathrm{E}}$ & $5.92 \pm 0.06^{\mathrm{C}}$ & $7.42 \pm 0.06^{\mathrm{A}}$ & $5.59 \pm 0.05^{\mathrm{D}}$ & $6.67 \pm 0.05^{\mathrm{B}}$ & $5.95 \pm 0.05^{\mathrm{B}}$ & $* * *$ & $* * *$ & $* * *$ \\
\hline
\end{tabular}

ns-not significant.

S0 sheep sausages without pork fat.

S10 sheep sausages with $10 \%$ of pork fat.

S30 sheep sausages with $30 \%$ of pork fat.

G0 goat sausages without pork fat.

G10 goat sausages with $10 \%$ of pork fat.

G30 goat sausages with $30 \%$ of pork fat.

* $P<0.05$.

** $P<0.01$.

*** $P<0.001$.

of texture attribute provided evidence that the lower abundance of fat content within the ground lean goat meat the higher force required to penetrate the sausage and the degree of deformation of the goat sausages before breaking. This result was in agreement with Lorenzo and Franco (2012) who reported that sausages with 30\% of fat had the lowest scores for hardness in foal dry-cured sausages produced with three different fat levels (10\%, $20 \%$ and $30 \%$ of fat).

Finally, overall acceptability was significantly $(P<0.001)$ affected by fat level and specie in both types of sausages. The goat sausages manufactured with higher fat content presented the highest scores ( 5.2 vs. 5.9 vs. 7.4 for control and 10 and $30 \%$ of pork fat added, respectively). This result is in disagreement with those noticed by Lorenzo and Franco (2012) who reported greater sensory characteristics for low and medium fat sausages.

\subsection{Discriminant analysis}

The $F$ values of all variables considered in the discriminant analysis carried out to determine if the six sausages groups could be distinguished on the basis of the fatty acids profile are shown in Table 4. The stepwise method selected the following variables in 3 steps: $\mathrm{C}$ 17:0, C20:1n9 and C18:3n3.

Scatter plot of the first two canonical variables of the six sausages groups considered (Fig. 1) showed that groups were discriminated with great accuracy with a total of $99.9 \%$ of variance explained, $91.19 \%$ and $8.75 \%$ for canonical 1 and canonical 2 functions, respectively. The first canonical function discriminates sausages manufactured with pork backfat that appeared on the positive side of the axis from the

Table 4

F values of all variables used in the discriminant analysis.

\begin{tabular}{lcc}
\hline Variable & F ratio & Prob $>F$ \\
\hline $\mathrm{C} 12: 0$ & 3.206 & 0.0092978 \\
$\mathrm{C} 14: 0$ & 665.666 & 0.0000000 \\
$\mathrm{C} 14: 1$ & 134.894 & 0.0000000 \\
$\mathrm{C} 16: 0$ & 89.850 & 0.0000000 \\
$\mathrm{C} 16: 1$ & 15.439 & 0.0000000 \\
$\mathrm{C} 17: 0$ & 3026.60 & 0.0000000 \\
$\mathrm{C} 17: 1$ & 821.753 & 0.0000000 \\
$\mathrm{C} 18: 0$ & 704.459 & 0.0000000 \\
$\mathrm{C} 18: 1 \mathrm{n} 9 \mathrm{c}$ & 89.899 & 0.0000000 \\
$\mathrm{C} 18: 1 \mathrm{n} 7 \mathrm{c}$ & 61.101 & 0.0000000 \\
$\mathrm{C} 18: 2 \mathrm{n} 6 \mathrm{c}$ & 200.602 & 0.0000000 \\
$\mathrm{C} 20: 0$ & 188.857 & 0.0000000 \\
$\mathrm{C} 20: 1 \mathrm{n} 9$ & 1971.70 & 0.0000000 \\
$\mathrm{C} 18: 3 \mathrm{n} 3$ & 87.632 & 0.0000000 \\
\hline
\end{tabular}

both control groups (manufactured without pork backfat) that are on the negative side of the axis.

The model accept a significant third canonical variable $(P<0.01)$, explaining a further $0.5 \%$ more of the total variance, and the $3 \mathrm{D}$ canonical plot in Fig. 2 shows that the model could discriminate the six groups of sausages with $100 \%$ a total variance explained accurately. The total of individuals of each group was assigned in the correct group pre-assigned, for $100 \%$ of classified correctly and the model is highly significant $(P<0.0001)$ for 0.00027 Wilks' lambda value.

The margaric acid in association with the eicosenoic and rumelenic fatty acids could be to discriminate goat and sheep sausages with different pork backfat percentages from the "halal" or "kosher" sausages without any quantity of pork backfat added. Xu, Cai, Cui, Ye, and Yu (2012) have studied the use of the discriminant analysis to discriminate the pork in halal and non-halal Chinese ham sausages. Also, Ortiz-Somovilla, España-España, De PedroSanz, and Gaitán-Jurado (2005) used the discriminant analysis to differentiate Iberian pork meat from standard pork meat and to detect any mixture levels of them in fresh sausages. Thus, the discriminant function would be an important traceability tool. This information would be interesting to producers and meat industry but also to consumers that need a guarantee at the moment to consume pork fat free sausages.

\subsection{General product evaluation}

Results show that the fat level is most important factor to determine the quality of the sausages Even though all sausages were appreciated by consumers the G30\%, followed by $\mathrm{S} 10 \%$ were the preferred ones. Once goat meat is learner than sheep meat, consumers prefer the goat sausages with the highest fat content and sheep sausages with the medium fat content. As already mentioned, the addition of pork backfat will reduce the amount of SFA, increase MUFA and PUFA and improve the ratio PUFA/SFA. The consumer preference will encounter with the best characteristics observed in the physic-chemical analyses determined in this study. We also noted that over $88 \%$ of consumers buy any of the products presented (data not shown). This fact allows us to say that there will be market for any of the fresh sausages presented in this work. It is important to note that the goat and sheep sausages without pork backfat would be directed marketing to halal and Kosher consumers.

\section{Conclusions}

Fresh sheep and goat sausages made with meat from culled animals is an interesting way to valorize a product with very low market acceptability, satisfying the interest of producers and introducing in the 


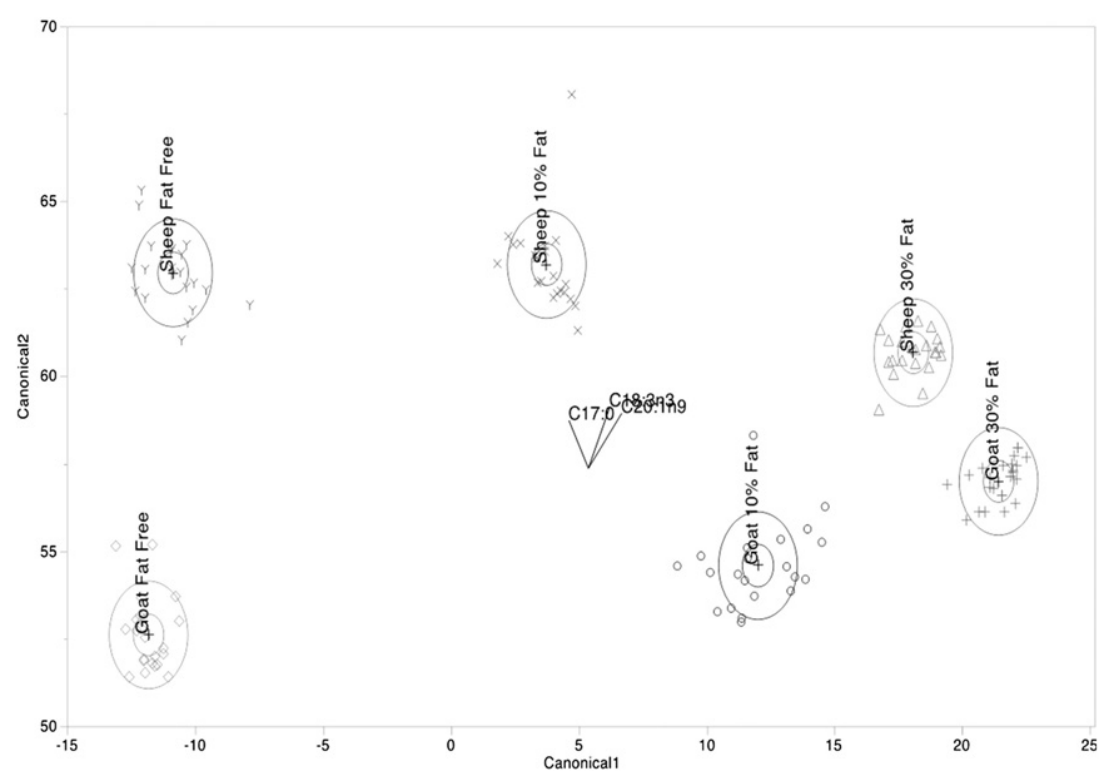

Fig. 1. Scatter plot of the first two canonical variables, of the six sausages groups considered (O, G10\%; +, G30\%; •, G0; $\times, \mathrm{S} 10 \% ; \Delta, \mathrm{S} 30 \% ; \Upsilon, \mathrm{S} 0)$.

market a new meat product. All physicochemical parameters were affected by the addition of pork backfat in both types of sausages. The addition of pork backfat modified the total fatty acid profile, prompting a significant drop in the relative percentages of the major fatty acids of sheep and goat meat. With the addition of pork fat has been observed an increase in oleic and linoleic acids. The addition of pork backfat in sausages led to an increase of PUFA/SFA ratio. It should be noted that the ratio PUFA $n 6 / n 3$ is impaired with the addition of pork backfat. Overall acceptability was significantly affected by fat level and the species in goat and sheep sausages. The goat sausages manufactured with higher fat content presented the highest scores of consumer preference.

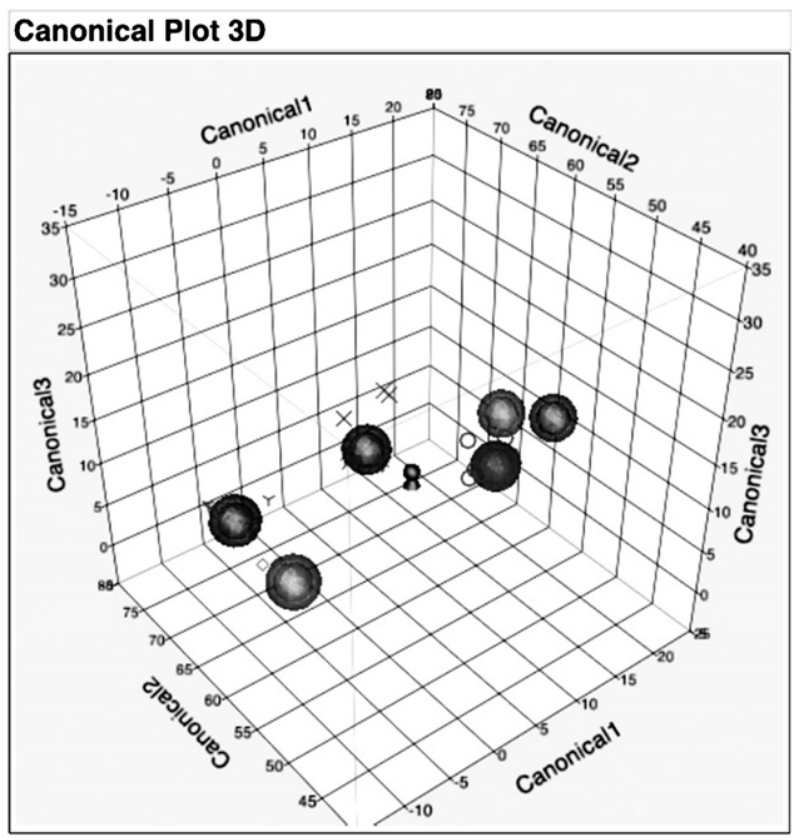

Fig. 2. Three-dimensional canonical plot considered (O, G10\%; +, G30\%;, $\mathrm{G0} ; \times, \mathrm{S} 10 \% ; \Delta$, S30\%; $\Upsilon$, S0).

\section{Acknowledgements}

Work included in the Portuguese PRODER research project number 020260013013 "New goat and sheep processed meat products" BISOVICAP-Processing meat from pigs, sheep and goats, to produce new products. Ham and paté, Project PROTEC, SI I\&DT-Projects in CoPromotion, no. 21511 and was supported by national funds (QREN/ PRODER/Medida 4.1).

\section{References}

Ambrosiadis, J., Soultos, N., Abrahim, A., \& Bloukas, J. G. (2004). Physicochemical, microbiological and sensory attributes for the characterization of Greek traditional sausages. Meat Science, 66, 279-287.

AOAC (1990). Official methods of analysis (15th ed.). Washington, DC: Association of Official Analytical Chemists.

Banskalieva, V., Sahlu, T., \& Goetsch, A. L. (2000). Fatty acid composition of goat muscles and fat depots: A review. Small Ruminant Research, 37, 255-268.

Bovolenta, S., Boscolo, D., Dovier, S., Morgante, M., Pallotti, A., \& Piasentier, E. (2008). Effect of pork lard content on the chemical, microbiological and sensory properties of a typical fermented meat product (Pitina) obtained from Alpagota sheep. Meat Science, 80, 771-779.

Cosenza, G. H., Williams, S. K., Johnson, D. D., Sims, C., \& McGowan, C. H. (2003). Development and evaluation of a cabrito smoked sausage product. Meat Science, 64(2), 119-124.

Das, A. K., Anjaneyulu, A. S. R., Thomas, R., \& Kondaiah, N. (2009). Effect of different fats on the quality of goat meat patties incorporated with full-fat soy paste. Journal of Muscle Foods, 20(1), 37-53.

Department of Health (1994). Nutritional aspects of cardiovascular disease. Report on health and social subjects. n.46, . London: HMSO (178 pp.).

Folch, J., Lees, M., \& Stanley, G. H. S. (1957). A simple method for isolation and purification of total lipids from animal tissues. Journal of Biological Chemistry, 226, 497-509.

Gómez, M., \& Lorenzo, J. M. (2013). Effect of fat level on physicochemical, volatile compounds and sensory characteristics of dry-ripened "chorizo" from Celta pig breed. Meat Science, 95, 658-666.

Henderson, C. R. (1973). Sire evaluation and genetic trends. Journal of Animal Science, 1973, 10-41 (doi:/1973.1973Symposium10x).

Liaros, N. G., Katsanidis, E., \& Bloukas, J. G. (2009). Effect of the ripening time under vacuum and packaging film permeability on processing and quality characteristics of low-fat fermented sausages. Meat Science, 83, 589-598.

Lorenzo, J. M., \& Franco, D. (2012). Fat effect on physico-chemical, microbial and textural changes through the manufactured of dry-cured foal sausage lipolysis, proteolysis and sensory properties. Meat Science, 92, 704-714.

Lorenzo, J. M., Montes, R., Purriños, L., Cobas, N., \& Franco, D. (2012). Fatty acid composition of Celta pig breed as influenced by sex and location in the carcass. Journal of the Science of Food and Agriculture, 92, 1311-1317.

Lorenzo, J. M., Purriños, L., Bermúdez, R., Temperan, S., \& Franco, D. (2011). Effect of fat level on physicochemical and sensory properties of dry-cured duck sausages. Poultry Science, 90, 1334-1339.

McMillin, K. W., \& Brock, A. P. (2005). Production practices and processing for valueadded goat meat. Journal Animal Science, 83, 57-68. 
NP-ISO-1612 (2002). Carnes e produtos cárneos. Determinação do teor de azoto total (Método de referência).

NP-ISO-1614 (2009). Determinação do teor de humidade (Método de referência).

NP-ISO-1615 (2002). Determinação da cinza total (Método de referência).

NP-ISO-3441 (2008). Determinação do pH (Método de referência).

NP-ISO-8586-1 (2001). Norma Portuguesa ISO 8586-1. Análise sensorial. Guia geral para a selecção, treino e controlo dos provadores.- Parte 1: Provadores qualificados.

Olivares, A., Navarro, J. L., Salvador, A., \& Flores, M. (2010). Sensory acceptability of slow fermented sausages based on fat content and ripening time. Meat Science, 86, 251-257.

Oliveira, A. F., Rodrigues, S., Leite, A., Paulos, K., Pereira, E., \& Teixeira, A. (2014). Short Communication: Quality of ewe and goat meat cured product mantas. An approach to provide value added to culled animals. Canadian Journal of Animal Science, 94(3), 459-462.

Ortiz-Somovilla, V., España-España, F., De Pedro-Sanz, E. J., \& Gaitán-Jurado, A. J. (2005). Meat mixture detection in Iberian pork sausages. Meat Science, 71, 490-497.

Polpara, Y., Sornprasitt, T., \& Wattanachant, S. (2008). Quality characteristics of raw and canned goat meat in water, brine, oil and Thai curry during storage. Journal of Science and Technology, 30(Suppl. 1), 41-50.

Rhee, K. S. (1992). Fatty acids in meat and meat products. In C. K. Chow (Ed.), Fatty acids in foods and their health implications (pp. 65-93). New York: Marcel.
Salazar, P., García, M. L., \& Selgas, M. D. (2009). Short-chain fructooligosaccharides as potencial functional ingrediente in dry fermented sausages with different fat levels. International Journal of Food Science and Technology, 44, 1100-1107.

Shehata, A. J., de Man, J. M., \& Alexander, J. C. (1970). A simple and rapid method for the preparation of methyl esters of fats in milligram amounts for gas chromatography. Canadian Institute of Food Science and Technology Journal, 3, 85-89.

Teixeira, A. (1995). Trends in small ruminant production in extensively managed areas of North East Portugal. Extensification of beef and sheep production on grassland.

Teixeira, A., Delfa, R., \& Alberti, P. (1998). Influence of production factors on the characteristics of meat from ruminants in Mediterranean area. In J. C. Flamant, D. Gabiña, \& M. Espejo Díaz (Eds.), Basis of the quality of typical Mediterranean animal products. EAAP Publication No. 90. 0071-2477. (pp. 315-319). Wageningen Academic90-74134-53-X.

Teixeira, A., Pereira, E., \& Rodrigues, S. (2011). Goat meat quality. Effects of salting, airdrying and ageing processes. Small Ruminant Research, 98(1-3), 55-58.

Turner, K. E. Cassida, K. A. \& Zerby, H. N. (2014). Meat goat kinds finished on alfalfa, red clover or orchardgrass pastures: Carcass merit and meat quality. Meat Science, 98, 629-636.

Xu, L., Cai, C. B., Cui, H. F., Ye, Z. H., \& Yu, X. P. (2012). Rapid discrimination of pork in halal and non-halal Chinese ham sausages by Fourier transform infrared (FTIR) spectroscop and chemometrics. Meat Science, 92, 506-510. 